DOI: https://doi.org/10.47405/mjssh.v5i8.456

\begin{tabular}{|c|c|}
\hline 1.sin & Malaysian Journal of Social Sciences and Humanities (MJSSH) \\
\hline $\begin{array}{l}\text { Malaysian Journal of } \\
\text { Socail sciences and }\end{array}$ & Volume 5, Issue 8, August 2020 \\
\hline $\begin{array}{l}\text { Humanities } \\
\text { (MJ - sSH) }\end{array}$ & e-ISSN : 2504-8562 \\
\hline & $\begin{array}{l}\text { Journal home page: } \\
\text { www.msocialsciences.com }\end{array}$ \\
\hline
\end{tabular}

\title{
Cadbury Malaysia Porcine DNA Case: Lessons from Crisis Management and Cultural Perspectives
}

\author{
Cheng-Zhen Yu1, Tak-Jie Chan ${ }^{1,2}$ \\ 1Faculty of Business, Social Sciences and Hospitality Management, SEGi University \\ 2Putra Business School, Universiti Putra Malaysia (UPM) \\ Correspondence: Cheng-Zhen Yu (fourheee@gmail.com)
}

\begin{abstract}
Crises are inevitable and it can be happened at any point of the organization process. Thus, it is worthwhile for the organization to identify the early plan of issue or potential risk occurring within organizations as it is not easy to win the reputation warfare. Thus, this paper aims to review the Cadbury Porcine DNA case that happened in Malaysia from the perspective of crisis management and cultural approaches. The discussion of the case surrounded on the chronology of the case, crisis communication and management strategies carried out by Cadbury and lessons learned from it. This has called upon the management, especially the public relations or corporate communication department to look into it to form a strategic solution to safeguard the organization's reputation when the crisis strike.
\end{abstract}

Keywords: crisis communication, public relations, corporate communication, strategic communication management

\section{Introduction}

In our daily life, no community, organization, public or private is immune from crisis as we live in a society that is continually affected by natural disasters, such as flood, tsunamis, forest fires, and organizational crisis, such as food borne illness, corporate malfeasance and other form of crises (Ulmer, Sellnow, \& Seeger, 2017). The aim of crisis management and communication is to exert control over events and organizational activities to reassure stakeholders are taken care of. Such control requires organizations to develop contingency plans to prepare for possible crises as well as communication plans to effectively respond to crisis scenarios.

This is in line with Coombs (2019) and Frandsen \& Johasen (2011), that crisis management includes efforts to mitigate crisis risks in order to prevent the occurrence of crises by developing three (3) stages: pre-crisis, crisis, and post-crisis. The other half is about the strategies in communicating effectively and responsibly. It is about taking actions to contain the crisis and limit the negative consequences for stakeholders and safeguard the organizations and its reputation (Cornelissen, 2020).

Hence, this paper aims to review the Cadbury Malaysia porcine DNA case from the viewpoint of crisis management and cultural lens. This discussion of the paper will focus on the chronology of the case, crisis management and communication strategies done by Cadbury. Lastly, this paper recommends 
DOI: https://doi.org/10.47405/mjssh.v5i8.456

some principles and lessons learned for effective organizational crisis management and communication.

\section{Background of Company}

In 1824, John Cadbury opens his first grocery store at the age of 22, which sells mustard, hops and a new kind of cocoa and drinking chocolate. Over the next two decades, with growing sales of cocoa and drinking chocolate, Cadbury expands its factories, the kinds of cocoa and drinking chocolate also increases to more than 20. His brother Benjamin Cadbury joined the company in 1847. By the early twentieth century, Cadbury opens its first overseas factory and became an international company. In 1970, Cadbury launches in Malaysia (Cadbury, 2020). Kraft Foods bought Cadbury in 2010 and split into Mondelez International in 2012. Now, Mondelez International is one of the world's largest snack companies (Mondelez International, 2019).

In Malaysia, Cadbury offers a host of delicious chocolates, such as Dairy Milk chocolates, toffee cookie, lickables, chocolate spread. It is committed in bringing the best chocolate products to local consumers (Cadbury, 2020). All products have passed the Halal authentication of Department of Islamic Development Malaysia (JAKIM), which aims to "protect the purity of faith and Islamic teachings" (Rahim \& Ali, 2017).

\section{Malaysia and Islam}

Malaysia is characterized by the large participation of government-controlled companies in many key industries, where Cadbury Malaysia is one of the entities in this respect. Mondelez international holds about $40 \%$ of shares, the other Cadbury's shares are held by two Malaysian government companies (Mondelez International, 2014). On the other hand, although Malaysia is a multi-ethnic country with laws based on English common law, the state and Islam are inextricably linked. Since Muslims make up more than two-thirds of the population, its social and political systems are heavily influenced by Islamic teaching which based on the Quran (Jaques, 2015). Hence, Halal food is a vital, huge and rapidly growing market in Malaysia market (Kasirye \& Kreya, 2020).

\section{Crisis that Cadbury have gone through}

The controversy crisis occurred on $23^{\text {rd }}$ May 2014, when a laboratory test report was leaked, it showed that two Cadbury Dairy Milk products contained porcine DNA (Musa, Muslim, Omar \& Husin, 2016). On the second day, the Malaysia Ministry of Health confirmed the finding of the report. JAKIM immediately suspended the Halal certification of the affected products and took other samples from the Cadbury plant's production line for further testing and investigation (Rahmah, 2014).

On $25^{\text {th }}$ May, Cadbury took the initiative to recall the batches of the affected products, promised on Facebook and its website that it would conduct a full review of its product line, to ensure that the product meets all safety and quality standards (Rahim \& Ali, 2017). Despite all this, public concerns and rumors about the contaminated products have escalated on various social media platforms, some Muslims called for a boycott of Cadbury products and its factories to stop operating. At the meantime, several NGOs were considering to take a joint lawsuit against Cadbury for RM100 million (Kasirye \& Kreya, 2020). Ministry of health, Ministry of standards, Ministry of agriculture and other departments' held the press conferences, but failed to solve the public's confusion and misunderstanding (Rahim \& Ali, 2017).

On 26 May 2014, the Health Ministry said in a press release that the issue of Halal certification would be handed over to JAKIM. In such a chaotic 10 days, Mondelez international lost about $\$ 37$ million in global sales (Jaques, 2015). In the face of growing criticism and unclear new test results, Cadbury Malaysia issued a carefully considered public relations statement, emphasized it is still working 
closely with Malaysian authorities and leaders of Muslim communities to assure them of its commitment to halal supervision (Kasirye \& Kreya, 2020).

$2^{\text {nd }}$ June 2014, JAKIM announced that new tests had been carried out on 11 product samples and no traces of porcine contamination had been found (BBC World News, 2014). Cadbury Malaysia immediately launched an advertisement blitz under the slogan "All is good, Enjoy us again". Cadbury stressed in the advertisement that their chocolate products in Malaysia is halal certified, and thanks Malaysian for believing them for 40 years. By this point, the crisis basically ended in less than two weeks and Cadbury product sales recovered. However, Cadbury Malaysia has not stopped its public relations campaign over the incident and it is still working to recover its image (Jaques, 2015). The following is the detailed chronology of this controversy crisis.

\begin{tabular}{|c|c|}
\hline Dates & Events \\
\hline 23 May 2014 & $\begin{array}{l}\text { - Confidential report of porcine DNA found in } 2 \text { batches of Cadbury Dairy } \\
\text { Milk chocolates went viral on social media }\end{array}$ \\
\hline 24 May 2014 & $\begin{array}{l}\text { - Ministry of Health issued a press release confirming the report's finding } \\
\text { - JAKIM suspended certification to Cadbury and took samples from the } \\
\text { factory for further investigation } \\
\text { - Cadbury Malaysia issued a statement on Facebook, reply users feedback } \\
\text { and told them investigation in process }\end{array}$ \\
\hline 25 May 2014 & $\begin{array}{l}\text { - A joint meeting was held by JAKIM, the Ministry of Health, the } \\
\text { Department of Standards and the Department of Chemistry to discuss the } \\
\text { controversy } \\
\text { - Cadbury Malaysia proactively recalled the affected product batches }\end{array}$ \\
\hline 26 May 2014 & $\begin{array}{l}\text { - the Ministry of Health issued a statement handed it to JAKIM } \\
\text { - Several NGOs wanted to jointly sue Cadbury for RM100 million }\end{array}$ \\
\hline 28 May 2014 & $\begin{array}{l}\text { - JAKIM confirmed that Cadbury followed halal production procedures, } \\
\text { and waiting for the Department of Chemistry to confirm whether Cadbury } \\
\text { products contained porcine DNA }\end{array}$ \\
\hline 30 May 2014 & $\begin{array}{l}\text { - Cadbury Malaysia issued first press statement in dual language telling } \\
\text { the public that it confident their chocolates are halal }\end{array}$ \\
\hline 2 June 2014 & $\begin{array}{l}\text { - Based on analysis by the Chemistry Department, JAKIM confirmed that } \\
\text { Cadbury products did not contain porcine DNA }\end{array}$ \\
\hline 3 June 2014 & $\begin{array}{l}\text { - Cadbury Malaysia issued second statement in dual language, which } \\
\text { saying all its products manufactured and sold in Malaysia are halal }\end{array}$ \\
\hline 6 June 2014 & $\begin{array}{l}\text { - Cadbury Malaysia took down its existing official website and replaced it } \\
\text { with a press release }\end{array}$ \\
\hline 18 July 2014 & $\begin{array}{l}\text { - Cadbury Malaysia released a dual language video to show consumers } \\
\text { how it ensures its products are halal }\end{array}$ \\
\hline 23 July 2014 & $\begin{array}{l}\text { - Cadbury Malaysia invited religious leaders and scholars to visit its } \\
\text { factory in Shah Alam }\end{array}$ \\
\hline
\end{tabular}

(Source: compiled by authors)

\section{Crisis Management and Communication Strategies by Cadbury}

\section{Speedy response and quick recall}

At the first moment of the incident, Cadbury Malaysia immediately issued a statement on its Facebook page, informing the public that Cadbury was aware of the situation, and stressed its position that all locally manufactured products were halal certified (Cadbury, 2014a). Despite at this time there were no instructions from government departments to request Cadbury to do anything, Cadbury proactively recalled the affected product batches on 25 May 2014 (Cadbury, 2014b). 


\section{Value public comments and feedback}

Cadbury Malaysia took the public sentiments seriously. On its Facebook, Cadbury Malaysia said that "we had heard from the public and we value comments and feedback over this issue" (Cadbury, 2014a). Although some of the comments were undoubtedly provocative, inflammatory and damaging, Cadbury has always been patient with public sentiment, listening to public concerns and telling publics that they will gave full cooperation to the authorities to investigate the issue with the highest urgency (Rahim \& Ali, 2017). Moreover, in order to cater for local consumers, the statement issued by Cadbury uses two languages, namely English and Malay.

\section{Respect religious culture}

At the beginning of the crisis, Cadbury did not question the test result of Malaysian Ministry of Health, and it believes that local Muslim consumers tend to value religious testing agencies over the views of foreign multinationals (Jaques, 2015). In this turmoil of the religious and political, Cadbury had always maintained a firm neutral position and it had waited patiently for the results of the investigation.

\section{Maximize communication channels and remain accessible}

Nowadays, the public usually gets information and learns risks or crises from the media (Veil \& Husted, 2012). Whether during the crisis or after the crisis, Cadbury Malaysia maximizes its use of the media and maintains accessibility, it issued statements on official website and Facebook, also conducted advertising campaigns on official website, Facebook and YouTube. Its accessibility enables the public and the media to know their attitudes and stand during the difficult times.

\section{Continually evaluate and repair image}

Cadbury Malaysia has resumed sales in less than two weeks, but its public relations campaign has not ended there. More than a month after the controversy, Cadbury Malaysia is still in the process of assessing its image repair. In addition to the online advertising blitz, religious leaders and scholars were invited to conduct offline visits. Through celebrity endorsement to show the public that their production process is strictly in accordance with halal standards, which strengthened its image restoration (Jaques, 2015).

\section{Lessons Learned}

\section{Be quick and try to have initial response within the first hour}

According to Coombs' (2019) best practices for initial crisis response, quickness plays an important role in handling the crisis (Breuklander, 2015).

Cadbury Malaysia made a statement the day after the incident, and voluntarily recalled the relevant products on the third day. Farrell Tan, who is the founding director of Orchan Consulting, he praised Cadbury Malaysia for handling this issue well and quickly. However, Lars Voedisch did not think so, he is managing director of Precious Communications, he did not think Cadbury Malaysia had solved the problem as soon as possible, as it should respond more quickly, not the next day or even the third day (Saim, 2014). Regardless of how Cadbury's response speed is assessed, the quicker response to the crisis, the less uncertainty and misinformation which better for its public relations (Breuklander, 2015). 


\section{Communicate with compassion}

Seeger's (2006) best practices argue that organizations must consider the public sentiment, avoid appearing callous while maintaining public trust and attention as these are key to minimize harm and starting the recovery process (Veil \& Husted, 2012).

Cadbury Malaysia keeps patient and sympathetic communication with the public when facing public questions and anger. Even for those extreme and inflammatory negative comments, Cadbury Malaysia did not delete by recognizing the public emotion and communicating compassionately. This can minimize the emotional damage to the public and damage to the reputation of the organization.

\section{Acknowledge and account for cultural differences}

Recognizing and understanding different cultures enable an organization to reach the groups more effectively during and after a crisis (Veil \& Husted, 2012). Especially in a multicultural market where politics and religion are closely interrelated, enterprises must recognize and respect mainstream social norms. For instance, in 2006, Japanese cosmetic SKII products sold in China were detected heavy metals. The company challenged the finding and stressed that tests conducted in other countries are qualified. The practice had caused resentment and anger among local SKII consumers paid a reputational and commercial cost for that (Jaques, 2015).

In this controversy, Cadbury Malaysia had reason to doubt the authenticity of the leaked report and could have taken a more active response, but it chose a gentle way, cooperate actively, and wait patiently for the new investigation result, wherein the strategy of not challenging JAKIM and the Ministry of Health was significant.

\section{Conclusion}

Cadbury's response is basically in line with the crisis communication strategies proposed by several western theories such as Situational Crisis Communication Theory, Benoit's Image Restoration Theory. By the standards of these theories, Cadbury's response may be too passive. However, its performance from a cultural point of view is effective.

This case provides several valuable lessons for managing the crisis that caused religious and political threats to a multinational brand. First, it is undisputed for all organizations to respond to crises in the first hour. Second, Cadbury uses multiple social media channels for continuous communication, which is informative, calm and helpful. In addition, company chose the effective strategies, respect for local cultural and social rules is a top priority, to protect its reputation and avoid aggravating the crisis.

\section{References}

BBC World News. (2014). Cadbury chocolate pork free, says Malaysian Islamic body. Retrieved from http://www.bbc.com/news/business-27663857

Breuklander, B. (2015). Responding to a rumor: How crisis response strategies influence relationship outcomes (Master thesis, University of South Florida, US). Retrieved from https://scholarcommons.usf.edu/etd/5450/

Cadbury. (2020). Our history. Retrieved from https://www.cadbury.com.my/our-history

Cadbury. (2014a). We at Cadbury would like to respond to the report. Cadbury Malaysia Facebook page. Retrieved fromhttps://www.facebook.com/CadburyMalaysia/posts/729333280443613

Cadbury. (2014b). We at Cadbury understand that customers are disappointed. Retrieved from https://www.facebook.com/CadburyMalaysia/posts/729797883730486

Coombs, W. T. (2019). Ongoing crisis communication: Planning, managing, and responding ( $\left.5^{\text {th }} \mathrm{ed}.\right)$. Thousand Oaks, California: Sage Publication.

Cornelissen, J. P. (2017). Corporate communication: A guide to the theory and practice (6 $6^{\text {th }}$ ed.). London: Sage Publication. 
DOI: https://doi.org/10.47405/mjssh.v5i8.456

Frandsen, F., \& Johasen, W. (2011). The study of internal crisis communication: Towards an integrative framework. Corporate Communications: An International Journal, 16(4), 347-361.

Jaques, T. (2015). Cadbury and pig DNA: When issue management intersects with religion. Corporate Communications: An International Journal, 20(4), 468-482.

Kasirye, F. \& Kreya, M. (2020). Assessing the 2014 Cadbury controversy through the Theory of Planned Behavior (Master thesis, International Islamic University Malaysia). doi:10.31124/advance.12012675.v1

Mondelez International. (2019). Annual Report 2019. Retrieved from http://www.annualreports.com/HostedData/AnnualReports/PDF/NASDAQ_MDLZ_2019.pdf

Mondelez International. (2014). Fact Sheet 2014. Retrieved from http://www.mondelezinternational.com/ /media/mondelezcorporate/Uploads/downloads/mo ndelez_intl_fact_sheet.pdf

Musa, N., Muslim, N., Omar, M. F. C., \& Husin, A. (2016). The Cadbury controversy: Blessing in disguise? Business Media Singapore, 95-104. doi:10.1007/978-981-10-1452-9_9

Rahm, N. R. A., \& Ali, M. N. (2017). Handling of crisis communication: A case study of Cadbury porcine DNA row. Institute for Management and Business Research $2^{\text {nd }}$ International Case Study Conference (ICSC) 2017.

Rahmah, G. (2014, May 24). JAKIM suspends "Halal" certification of two Cadbury products. The Star. Retrieved from https://www.thestar.com.my/News/Nation/2014/05/24/Jakim-Cadburychocolates/?fbclid=IwAR215dA4QjkA8TbbWZeFzZgnP1UL2x7MWfnZp_NdEQz3v1O4XspGcjfwzw

Saim, Q. (2014). Porcine DNA crisis: Did Cadbury manage communications well? Retrieved from https://www.marketing-interactive.com/cadbury-recalls-two-products/

Seeger, M.W. (2006). Best practices in crisis communication: an expert panel process. Journal of Applied Communication Research, 34(3), 232-244.

Ulmer, R. R., Sellnow, T. L., \& Seeger, M. W. (2017). Effective crisis communication: Moving from crisis to opportunity $\left(4^{\text {th }}\right.$ ed.). Thousand Oaks, California: Sage Publications.

Veil, S. R., \& Husted, A. (2012). Best practices as an assessment for crisis communication. Journal of Communication Management, 16(2), 131-145. 